\begin{tabular}{|c|c|c|}
\hline 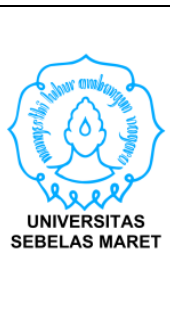 & $\begin{array}{l}\text { DWIJACENDEKIA Jurnal Riset Pedagogik } 1 \text { (2) (2017) 1-13 } \\
\text { DWIJACENDEKIA } \\
\text { Jurnal Riset Pedagogik } \\
\text { https://jurnal.uns.ac.id/jdc }\end{array}$ & 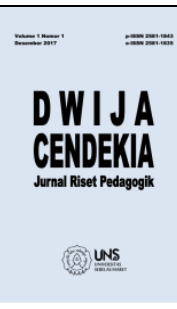 \\
\hline
\end{tabular}

\title{
PENINGKATAN KOMPETENSI GURU SDN TUNJUNGSEKAR 5 MALANG DALAM PENYUSUNAN RPP BERBASIS TEMATIK TERPADU MELALUI MODEL DOUBLE EXPERT GROUPS JIGSAW
}

\section{Agus Sriwulan}

SDN Tunjungsekar 5 Kota Malang

\section{Sejarah Artikel}

Diterima 15 September 2017

Disetujui 13 Oktober 2017

Diterbitkan 1 Desember 2017

\section{Kata Kunci}

model kooperatif tipe

Double Expert Groups

Jigsaw, kompetensi guru, RPP berbasis tematik terpadu

\begin{abstract}
Abstrak
Penelitian ini bertujuan untuk meningkatkan kompetensi guru SDN Tunjungsekar 5 Malang dalam penyusunan RPP berbasis tematik terpadu melalui model penerapan model Double Expert Groups Jigsaw. Jenis penelitian ini merupakan Penelitian Tindakan Sekolah yang terdiri dari 2 siklus. Masingmasing siklus terdiri dari empat tahap, yaitu tahap perencanaan, pelaksanaan, pengamatan, dan refleksi. Subyek penelitian ini adalah seluruh guru SDN Tunjungsekar 5 Malang tahun pelajaran 2016/2017 yang berjumlah 12 orang terdiri dari 9 guru perempuan dan 3 guru laki-laki. Data tentang kompetensi guru SDN Tunjungsekar 5 Malang dalam penyusunan RPP berbasis tematik terpadu dan keterlaksanaan model Double Expert Groups Jigsaw dikumpulkan melalui lembar observasi dan angket. Data yang telah terkumpul kemudian dianalisis dengan menggunakan teknik analisis deskriptif kualitatif. Data hasil penelitian tentang keterlaksanaan model Double Expert Groups Jigsaw mengalami peningkatan yang signifikan sebesar $52 \%$ pada siklus I menjadi $90 \%$ pada siklus II. Peningkatan yang sama juga terjadi pada kompetensi guru SDN Tunjungsekar 5 Malang dalam penyusunan RPP berbasis tematik terpadu diperoleh hasil sebesar $63 \%$ pada siklus I dan $82 \%$ pada siklus II. Berdasarkan hasil penelitian tersebut, dapat disimpulkan bahwa kompetensi guru SDN Tunjungsekar 5 Malang dalam penyusunan RPP berbasis tematik terpadu mengalami peningkatan yang dijembatani oleh keefektifan model Double Expert Groups Jigsawyang dilakukan oleh guru.
\end{abstract}

\section{Cara Mengutip}

Sriwulan, A. (2017). Peningkatan Kompetensi Guru SDN Tunjungsekar 5 Malang dalam Penyusunan RPP Berbasis Tematik Terpadu Melalui Model Double Expert Groups Jigsaw. DWIJACENDEKIA Jurnal Riset Pedagogik, 1(2), 1-13. 


\section{PENDAHULUAN}

Salah satu kunci sukses yang menentukan keberhasilan implementasi kurikulum 2013 adalah kompetensi guru. Kompetensi yang dimiliki guru berpengaruh besar pada penentuan keberhasilan belajar peserta didik. Kurikulum 2013 yang berbasis karakter dan kompetensi, ingin mengubah pola pendidikan dari orientasi hasil menuju orientasi pendidikan sebagai proses melalui pembelajaran tematik terpadu.

Sebagaimana pola pikir di atas, maka pada prinsipnya kompetensi yang diharapkan dikuasai oleh guru adalah kompetensi dalam merencanakan pembelajaran yang aktif, produktif, efektif, dan bermakna bagi peserta didik. Senada dengan Peraturan Menteri Pendidikan dan Kebudayaan Republik Indonesia No. 103 Tahun 2014 yang memuat bahwa pembelajaran pada tingkat pendidikan dasar dilaksanakan berbasis scientific yang disusun melalui rencana pelaksanaan pembelajaran (RPP).

Secara harfiah, RPP merupakan proses pendidikan yang memberikan kesempatan kepada peserta didik untuk mengembangkan potensi mereka menjadi kemampuan yang semakin lama semakin meningkat dalam aspek pengetahuan, keterampilan, dan sikap (Anderson \& Krathwohl, 2001). Oleh karena itu, kegiatan pembelajaran diarahkan untuk memberdayakan semua potensi peserta didik menjadi kompetensi yang diharapkan dalam kurikulum 2013. Lebih lanjut, strategi pembelajaran yang dipilih harus diarahkan untuk memfasilitasi pencapaian kompetensi yang telah disusun dalam dokumen kurikulum yang mencakup aspek (1) student centre, (2) mengembangkan kreativitas peserta didik, (3) menciptakan kondisi yang menyenangkan dan menantang, (4) memuat nilai etika, estetika, logika, dan kinestetika, (5) menyediakan pengalaman belajar yang beragam melalui penerapan berbagai strategi dan metode pembelajaran yang menyenangkan, kontekstual, efektif, efisien, dan bermakna (Widyastono, 2014).

Berdasarkan hasil observasi yang dilakukan peneliti pada tanggal 12-19 Juli 2016 ditemukan bahwa banyak guru yang tidak menyusun RPP berdasarkan karya dan pemikiran mereka sendiri, melainkan mengcopypaste milik teman di sekolah lain atau bahkan mengunduh dari internet. Hal ini menunjukkan bahwa kurangnya kreativitas dan eksplorasi guru untuk mengembangkan kemampuan dalam tugasnya sebagai pendidik.

Berdasarkan hasil wawancara tidak terstruktur dengan beberapa guru di SDN Tunjungsekar 5 Malang, terungkap bahwa adanya kesulitan dan ketidakpahaman guru tentang metode, strategi, atau model sehingga guru beranggapan bahwa ketiganya merupakan hal yang sama. Selain itu, adanya alasan kerumitan pada pemahaman tematik terpadu menjadi faktor utama guru memilih cara singkat dan simple dalam mempersiapkan RPP.

Kurangnya pemahaman guru dalam menyusun RPP didasari oleh kurangnya sosialisasi secara berkesinambungan dan kurangnya pemahaman guru tentang makna dari 
pembelajaran berbasis tematik terpadu. Ketika guru akan merencanakan pembelajaran, maka diperlukan adanya identifikasi standar, sasaran-sasaran dalam pembelajaran, dan aktivitas yang mampu mendorong sasaran pembelajaran tercapai (Wiggins \& McTighe, 2005). Dalam tematik terpadu, terdapat lima prinsip yang menjadi pedoman penyusunan RPP, yaitu (a) berpusat pada peserta didik, (b) bersifat fleksibel, (c) pembelajaran sesuai minat dan kebutuhan peserta didik, (d) menggunaan prinsip belajar yang menyenangkan, (e) pembelajaran peserta didik aktif. (Permendikbud No. 103, 2014).

Upaya yang dapat lakukan peneliti dalam mengatasi permasalahan yang berkaitan dengan kompetensi guru dalam penyusunan RPP adalah melakukan drill concept melalui model tim ahli. Melalui kerja tim, guru dapat belajar bersama, saling berbagi, saling mengembangkan kemampuan untuk menyusun RPP berdasarkan lima prinsip tematik terpadu yang dijabarkan di atas.

Berdasarkan latar belakang masalah di atas, maka permasalahan yang akan menjadi fokus penelitian ini adalah bagaimana penerapan model Double Expert Groups Jigsaw untuk meningkatkan kompetensi guru SDN Tunjungsekar 5 Malang dalam penyusunan RPP berbasis tematik terpadu?

Hasil penelitian ini diharapkan akan memberi manfaat (1) Bagi guru, dapat dijadikan sumber informasi dalam mengembangkan kompetensi yang berkaitan tentang penyusunan RPP, (2) Bagi sekolah, dapat memberikan alternatif jalan keluar untuk mengatasi kendala-kendala yang bersifat akademik sehingga dapat meningkatkan kualitas pembelajaran di sekolah,(3) Bagi peneliti lain, dapat dijadikan rujukan dalam mengembangkan penelitian yang sejenis.

\section{METODE PENELITIAN}

Penelitian ini menggunakan pendekatan deskriptif kualitatif. Menurut jenisnya penelitian ini menggunakan rancangan Penelitian Tindakan Sekolah yang dilaksanakan pada semester 1 tahun pelajaran 2016/2017 di SDN Tunjungsekar 5 Malang. Penelitian ini dipilih karena dilakukan untuk memecahkan masalah pembelajaran dengan terperinci dimulai dari observasi awal sampai pemilihan model yang sesuai dengan permasalahan yang muncul. Kemmis \& Taggart (2014: 11) mengemukakan bahwa penelitian tindakan tindakan adalah penyelidikan melalui pengumpulan data oleh seseorang dengan maksud membuat penilaian tentang cara dan teknik untuk meningkatkan kualitas peneliti. Subyek penelitian ini adalah guru SDN Tunjungsekar 5 Malang sebanyak 12 orang yang terdiri dari 3 guru laki-laki dan 9 guru perempuan. Selanjutnya, penelitian ini dilaksanakan dalam 2 siklus, setiap siklus memuat tahapan perencanaan, pelaksanaan dan pengamatan, refleksi (Kemmis \& Taggart (2014: 19). Desain penelitian ini dapat digambarkan dengan model sebagai berikut. 


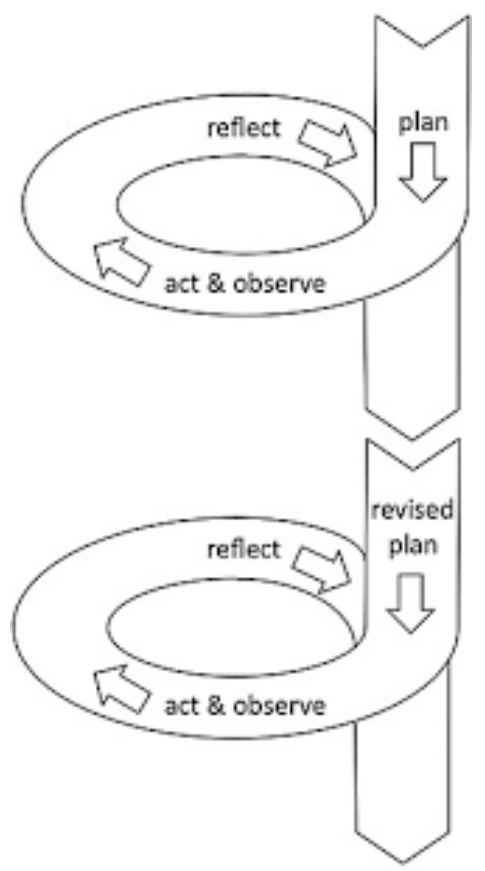

Gambar 1. Desain Penelitian Tindakan Kelas Model Spiral Kemmis \& Taggart. (Diadaptasi: Kemmis dkk., 2014: 19)

Pada tahap perencanaan ini yang dilakukan oleh peneliti meliputi; (a) menentukan kelompok; (b) menyusun dan menyiapkan model Double Expert Groups Jigsaw; (c) membuat instrumen penelitian yaitu lembar observasi dan angket.

Pelaksanaan tindakan ini disesuaikan dengan perencanaan yang telah disusun berdasarkan model Double Expert Groups Jigsaw. Diawali dengan tahap sosiali tentang sintaks model Double Expert Groups Jigsaw dan pembagian kelompok. Selanjutnya menerapkan model Double Expert Groups Jigsaw.Sedangkan kegiatan observasi dalam penelitian ini dilakukan terhadap pelaksanaan tindakan yang dilakukan selama pelaksanaan pembelajaran. Hal-hal yang perlu diamati oleh observer adalah kegiatan permainan model dan penyusunan RPP oleh guru.
Kegiatan observasi dalam penelitian ini dilakukan terhadap pelaksanaan tindakan yang dilakukan selama pelaksanaan pembelajaran. Hal-hal yang perlu diamati oleh observer adalah keterampilan sosial siswa dalam dalam kelompok yang meliputi sub aspek (1) kemampuan berkomunikasi dengan siswa lain, (2) menjalin hubungan pertemanan dengan teman sebaya, mendengarkan pendapat teman, (4) memberi dan menerima kritik dari orang lain, dan (5) memberi atau menerima umpan balik.

Refleksi dilakukan berdasarkan hasil observasi dan angket penelitian berdasarkan indikator keberhasilan yang ditetapkan yaitu $\geq 70 \%$. Pada tahap ini, peneliti dan kolaborator mendiskusikan hasil observasi dan angket kemudian mengevaluasi semua kegiatan yang dilakukan dalam proses penelitian.

Data yang diproleh dari hasil observasi dan angketdianalisis dengan menggunakan teknik analisis data deskriptif kualitatif untuk memastikan bahwa penerapan model Double Expert Groups Jigsawdapat meningkatkan kompetensi guru SDN Tunjungsekar 5 Malang dalam penyusunan RPP berbasis tematik terpadu. Selanjutnya, data dievaluasi untuk mengetahui keberhasilan tindakan atau sebagai acuan tindak lanjut siklus. Adapun kriteria evaluasi keberhasilan per siklus pada tabel berikut. 
Tabel 1. Kriteria Keberhasilan Tindakan

\begin{tabular}{|c|c|c|c|}
\hline No & Aspek & Sub Aspek & $\begin{array}{c}\text { Target Pencapaian } \\
\text { Rata-rata kelas dalam } \\
\text { Prosentase }\end{array}$ \\
\hline \multirow[t]{3}{*}{1.} & $\begin{array}{l}\text { Model Double } \\
\text { Expert Groups }\end{array}$ & $\begin{array}{l}\text { Keaktifan dalam kerja } \\
\text { tim }\end{array}$ & \multirow{3}{*}{$70 \%$} \\
\hline & Jigsaw & Kontribusi kepada tim & \\
\hline & & Efektifitas kerja tim ahli & \\
\hline \multirow[t]{3}{*}{2.} & RPP berbasis & Model Pembelajaran & \multirow{3}{*}{$70 \%$} \\
\hline & tematik terpadu & $\begin{array}{l}\text { Media atau sumber } \\
\text { belajar }\end{array}$ & \\
\hline & & $\begin{array}{l}\text { Langkah-langkah } \\
\text { pembelajaran }\end{array}$ & \\
\hline
\end{tabular}

(Olahan peneliti, 2016)

\section{PEMBAHASAN}

Hasil Siklus I

Berdasarkan observasi dan angketkepada 12 subyek penelitiantentang keterlaksanaan model Double Expert Groups
Jigsawdan kompetensi guru SDN Tunjungsekar 5 Malang dalam penyusunan RPP berbasis tematik terpadu diperoleh hasil pada tabel berikut:

Tabel 2.Hasil observasi dan Angket Keterlaksanaan Model Double Expert Groups Jigsaw Siklus I

\begin{tabular}{|c|c|c|c|c|c|}
\hline \multirow{2}{*}{ No } & \multirow{2}{*}{ Aspek } & \multirow{2}{*}{ Sub Aspek } & \multirow{2}{*}{$\begin{array}{l}\text { Sebelum } \\
\text { Tindakan }\end{array}$} & \multicolumn{2}{|c|}{ Setelah Tindakan } \\
\hline & & & & 0 & A \\
\hline \multirow[t]{3}{*}{1} & $\begin{array}{l}\text { Keterlaksanaan } \\
\text { model Double } \\
\text { Expert Groups } \\
\text { Jigsaw }\end{array}$ & $\begin{array}{l}\text { Keaktifan guru dalam } \\
\text { kegiatan berdiskusi } \\
\text { atau bekerjasama } \\
\text { dengan teman lain } \\
\text { untuk memecahkan } \\
\text { masalah. }\end{array}$ & \multirow{3}{*}{$\begin{array}{l}0 \% \text { (belum } \\
\text { pernah } \\
\text { diterapkan) }\end{array}$} & $50 \%$ & $67 \%$ \\
\hline & & $\begin{array}{l}\text { Kontribusi masing- } \\
\text { masing guru dalam } \\
\text { kegiatan diskusi }\end{array}$ & & $42 \%$ & $33 \%$ \\
\hline & & $\begin{array}{l}\text { Efektifitas dua tim ahli } \\
\text { dalam diskusi di } \\
\text { kelompok tim ahli dan } \\
\text { kelompok asal }\end{array}$ & & $50 \%$ & $67 \%$ \\
\hline \multicolumn{2}{|c|}{ Rata-Rata } & & $0 \%$ & $47 \%$ & $56 \%$ \\
\hline \multicolumn{3}{|c|}{$\begin{array}{l}\text { Rata-rata keterlaksanaan model Double } \\
\text { Expert Groups Jigsaw }\end{array}$} & \multicolumn{3}{|c|}{$52 \%$} \\
\hline
\end{tabular}


Berdasarkan tabel 2 dapat diketahui adanya peningkatan yang cukup signifikan pada aspek keterlaksanaan model Double Expert Groups Jigsaw dari 0\% atau belum pernah diterapkan menjadi $52 \%$ pada tindakan di siklus I ini. Hasil ini menunjukkan adanya penerimaan yang positif dari guru dalam penerapan model Double Expert Groups Jigsaw.Rata-rata ketercapaian sub aspek keaktifan guru dalam kegiatan berdiskusi atau bekerjasama diperoleh hasil sebesar 59\%, dengan kata lain hampir sebagian guru belum memiliki kepedulian dan keinginan untuk bekerjasama menghadapi kendala-kendala tugas kelompok. Rata-rata ketercapaian sub aspek peran serta guru dalam diskusi diperoleh hasil sebesar 38\%, dapat diartikan bahwa masih rendahnya kontribusi, empati, dan kemauan guru untuk meringankan tugas kelompok yang dibebankan. Ratarata ketercapaian sub aspek efektifitas tim ahli diperoleh hasil sebesar $59 \%$, yang dapat diartikan belum efektifnya kinerja yang dilakukan oleh tim ahli dalam kaitan tugasnya sebagai penyampai informasi.

Tabel 3. Hasil observasi dan Angket Kemampuan Guru Dalam Menyusun RPP Berbasis Tematik Terpadu Siklus I

\begin{tabular}{|c|c|c|c|c|c|}
\hline \multirow{2}{*}{ No } & \multirow{2}{*}{ Aspek } & \multirow{2}{*}{ Sub Aspek } & \multirow{2}{*}{$\begin{array}{c}\text { Sebelum } \\
\text { Tindakan }\end{array}$} & \multicolumn{2}{|c|}{ Setelah Tindakan } \\
\hline & & & & 0 & $\mathbf{A}$ \\
\hline \multirow[t]{3}{*}{1} & \multirow{3}{*}{$\begin{array}{l}\text { Kemampuan } \\
\text { guru } \\
\text { menyusun } \\
\text { RPP } \\
\text { berbasis } \\
\text { tematik } \\
\text { terpadu }\end{array}$} & $\begin{array}{l}\text { Penggunaan model } \\
\text { pembelajaran } \\
\text { kooperatif }\end{array}$ & $33 \%$ & $50 \%$ & $67 \%$ \\
\hline & & $\begin{array}{l}\text { Penggunaan media } \\
\text { berbasis teknologi } \\
\text { dan lingkungan }\end{array}$ & $67 \%$ & $42 \%$ & $33 \%$ \\
\hline & & $\begin{array}{l}\text { Skenario } \\
\text { pembelajaran yang } \\
\text { meliputi, mengamati, } \\
\text { menanya, } \\
\text { mengumpulkan data, } \\
\text { menganalisis, dan } \\
\text { mengkomunikasikan. }\end{array}$ & $42 \%$ & $50 \%$ & $67 \%$ \\
\hline \multicolumn{2}{|c|}{ Rata-Rata } & & $47 \%$ & $58 \%$ & $67 \%$ \\
\hline \multicolumn{3}{|c|}{$\begin{array}{l}\text { Rata-rata kemampuan guru menyusun } \\
\text { RPP berbasis tematik terpadu }\end{array}$} & \multicolumn{3}{|c|}{$63 \%$} \\
\hline
\end{tabular}

(Sumber: Hasil Observasi dan Angket Kemampuan Guru Dalam Menyusun RPP Berbasis Tematik Terpadu Siklus I olahan peneliti, 2016).

Berdasarkan tabel 3 tentang hasil observasi dan angket kemampuan guru dalam menyusun RPP tematik terpadu pengalami peningkatan dari
$47 \%$ menjadi 63\%. Rata-rata ketercapaian sub aspek penggunaan model pembelajaran kooperatif diperoleh hasil sebesar 
59\% memiliki keterkaitan dengan rata-rata ketercapaian sub aspek skenario pembelajaran melalui lima kegiatan belajar sebesar $59 \%$, yang dapat diartikan implementasi model kooperatif disisipkan pada tiap-tiap kegiatan belajar. Diawali dengan kegiatan mengamati oleh kelompok sampai dengan kegiatan mengkomunikasikan hasil diskusi kelompok. Peran kelompok inilah yang menjadi penanda adanya penerapan model kooperatif dalam skenario atau langkah-langkah pembelajaran yang dirancang oleh guru. Sedangkan rata-rata $\begin{array}{rrr}\text { ketercapaian } & \text { sub } & \text { aspek } \\ \text { penggunaan } & \text { media } & \text { berbasis }\end{array}$ teknologi diperoleh hasil sebesar $38 \%$ yang mengindikasikan kemampuan guru untuk memanfaatkan media berbasis teknologi masih kurang, terbatas pada guru berusia produktif yang memiliki kreatifitas dan inovasi dalam pemanfaatan media tersebut. Berdasarkan paparan di atas, jika dilakukan analisis keberhasilan siklus I, maka dapat digambarkan pada tabel sebagai berikut.

Tabel 4. Analisis Keberhasilan Siklus I

\begin{tabular}{clccc}
\hline No & \multicolumn{1}{c}{ Aspek } & $\begin{array}{c}\text { Kriteria } \\
\text { Keberhasilan }\end{array}$ & $\begin{array}{c}\text { Hasil } \\
\text { Siklus I I }\end{array}$ & Keterangan \\
\hline 1 & $\begin{array}{l}\text { Keterlaksanaan model Double } \\
\text { Expert Groups Jigsaw }\end{array}$ & $\geq 70 \%$ & $52 \%$ & $\begin{array}{c}\text { Belum } \\
\text { berhasil }\end{array}$ \\
\hline 2 & $\begin{array}{l}\text { Kemampuan guru dalam } \\
\text { menyusun RPP berbasis tematik } \\
\text { terpadu }\end{array}$ & $\geq 70 \%$ & $63 \%$ & $\begin{array}{c}\text { Belum } \\
\text { berhasil }\end{array}$ \\
\hline
\end{tabular}

(Sumber: olahan peneliti, 2016)

Data hasil analisis siklus I di atas menunjukkan bahwa keseluruhan aspek yang diteliti belum mencapai kriteria keberhasilan tindakan.

\section{Hasil Siklus II}

$\begin{array}{lcr}\text { Berdasarkan } & \text { observasi } & \text { dan } \\ \text { angketkepada } & 12 & \text { subyek } \\ \text { penelitiantentang } & \text { keterlaksanaan } \\ \text { model Double } & \text { Expert Groups }\end{array}$

Mengacu pada hasil tersebut, maka peneliti dan observer menyepakati adanya kelanjutan tindakan ke siklus

II.

Jigsawdan kompetensi guru SDN Tunjungsekar 5 Malang dalam penyusunan RPP berbasis tematik terpadu diperoleh hasil pada tabel berikut. 
Tabel 5. Hasil observasi dan Angket Keterlaksanaan Model Double Expert Groups Jigsaw Siklus II

\begin{tabular}{|c|c|c|c|c|}
\hline No & Aspek & Sub Aspek & $\mathbf{O}$ & $\mathbf{A}$ \\
\hline \multirow[t]{3}{*}{1} & \multirow{3}{*}{$\begin{array}{l}\text { Keterlaksanaan } \\
\text { model Double } \\
\text { Expert Groups } \\
\text { Jigsaw }\end{array}$} & $\begin{array}{l}\text { Keaktifan guru dalam kegiatan berdiskusi } \\
\text { atau bekerjasama dengan teman lain } \\
\text { untuk memecahkan masalah. }\end{array}$ & $83 \%$ & $100 \%$ \\
\hline & & $\begin{array}{l}\text { Kontribusi masing-masing guru dalam } \\
\text { kegiatan diskusi }\end{array}$ & $75 \%$ & $83 \%$ \\
\hline & & $\begin{array}{l}\text { Efektifitas dua tim ahli dalam diskusi di } \\
\text { kelompok tim ahli dan kelompok asal }\end{array}$ & $100 \%$ & $100 \%$ \\
\hline \multicolumn{3}{|c|}{ Rata-Rata } & $86 \%$ & $94 \%$ \\
\hline \multicolumn{3}{|c|}{ Rata-rata keterlaksanaan model Double Expert Groups Jigsaw } & \multicolumn{2}{|c|}{$90 \%$} \\
\hline
\end{tabular}

Berdasarkan tabel 5 tentang hasil observasi dan angket tentang keterlaksanaan model Double Expert Groups Jigsaw diperoleh hasil sebesar $90 \%$. Rata-rata ketercapaian sub aspek keaktifan guru dalam kegiatan berdiskusi atau bekerjasama diperoleh hasil sebesar 92\%, dengan kata lain hampir seluruh guru memiliki kepedulian dan keinginan untuk bekerjasama menghadapi kendalakendala tugas kelompok. Rata-rata ketercapaian sub aspek peran serta guru dalam diskusi diperoleh hasil sebesar $79 \%$, dapat diartikan bahwa munculnya kontribusi, empati, dan kemauan guru untuk meringankan tugas kelompok yang dibebankan. Rata-rata ketercapaian sub aspek efektifitas tim ahli diperoleh hasil sebesar $100 \%$, yang dapat diartikan kinerja tim ahli efektif baik dalam kelompok tim ahli maupun kelompok asal.

Tabel 6. Hasil observasi dan Angket Kemampuan Guru Dalam Menyusun RPP Berbasis Tematik Terpadu Siklus II

\begin{tabular}{|c|c|c|c|c|}
\hline No & Aspek & Sub Aspek & 0 & $\mathbf{A}$ \\
\hline \multirow[t]{3}{*}{1} & \multirow{3}{*}{$\begin{array}{l}\text { Kemampuan } \\
\text { guru dalam } \\
\text { menyusun } \\
\text { RPP berbasis } \\
\text { tematik } \\
\text { terpadu }\end{array}$} & $\begin{array}{l}\text { Penggunaan model pembelajaran } \\
\text { kooperatif }\end{array}$ & $75 \%$ & $83 \%$ \\
\hline & & $\begin{array}{l}\text { Penggunaan media berbasis teknologi dan } \\
\text { lingkungan }\end{array}$ & $83 \%$ & $75 \%$ \\
\hline & & $\begin{array}{l}\text { Skenario pembelajaran yang meliputi, } \\
\text { mengamati, menanya, mengumpulkan data, } \\
\text { menganalisis, dan mengkomunikasikan. }\end{array}$ & $83 \%$ & $92 \%$ \\
\hline \multicolumn{2}{|c|}{ Rata-Rata } & & $80 \%$ & $83 \%$ \\
\hline \multicolumn{3}{|c|}{ Rata-rata keterlaksanaan model Double Expert Groups Jigsaw } & \multicolumn{2}{|c|}{$82 \%$} \\
\hline
\end{tabular}

Berdasarkan table 6 tentang hasil observasi dan angket kemampuan guru dalam menyusun RPP tematik terpadu diperoleh hasil sebesar $82 \%$. Rata-rata ketercapaian sub aspek penggunaan model 
pembelajaran kooperatif diperoleh hasil sebesar $79 \%$ memiliki keterkaitan dengan rata-rata ketercapaian sub aspek penggunaan media berbasis teknologi dan lingkungan. Dapat dikatakan guru memiliki kemampuan untuk mengembangkan pembelajarannya melalui penerapan model kooperatif yang dikombinasikan dengan pemanfaatan media seperti powerpoint dan video. Sedangkan rata-rata ketercapaian sub aspek skenario pembelajaran melalui lima kegiatan belajar (mengamati, menanya, mengumpulkan data, menganalisis, dan mengkomunikasikan) diperoleh hasil sebesar $88 \%$, yang dapat disimpulkan bahwa adanya kemampuan hampir seluruh guru untuk memberikan pengalaman belajar yang menyenangkan, aktif, dan bermakna bagi siswa.

Mengacu pada paparan di atas, jika dilakukan analisis keberhasilan siklus II, maka dapat digambarkan pada tabel sebagai berikut.

Tabel 4.9 Analisis Keberhasilan Siklus II

\begin{tabular}{clccc}
\hline No & \multicolumn{1}{c}{ Aspek } & $\begin{array}{c}\text { Kriteria } \\
\text { Keberhasilan }\end{array}$ & $\begin{array}{c}\text { Hasil } \\
\text { Siklus } \\
\text { II }\end{array}$ & Keterangan \\
\hline 1 & $\begin{array}{l}\text { Keterlaksanaan model Double } \\
\text { Expert Groups Jigsaw }\end{array}$ & $\geq 70 \%$ & $90 \%$ & Berhasil \\
\hline 2 & $\begin{array}{l}\text { Kemampuan guru dalam } \\
\text { menyusun RPP berbasis tematik } \\
\text { terpadu }\end{array}$ & $\geq 70 \%$ & $82 \%$ & Berhasil \\
\hline
\end{tabular}

(Sumber: olahan peneliti, 2016)

Data hasil analisis siklus II di atas menunjukkan. menunjukkan bahwa keterlaksanaan model Double Expert Groups Jigsaw diperoleh $90 \%$ atau di atas kriteria keberhasilan sebesar $\quad \geq 70 \%$. Artinya, keterlaksanaan model Double Expert Groups Jigsaw pada sub aspek memahami melakukan diskusi, berkontribusi aktif dalam kelompok, dan kinerja tim ahli yang efektif dinyatakan berhasil. Sementara perolehan nilai pada aspek kemampuan guru dalam menyusun RPP tematik terpadu diperoleh $82 \%$, di atas kriteria keberhasilan sebesar $\geq 70 \%$ dapat dikatakan bahwa kemampuan guru dalam menyusun RPP tematik terpadu pada sub aspek kemampuan menerapkan model kooperatif, menggunakan media berbasis teknologi atau lingkungan, dan penerapan lima kegiatan belajar dinyatakan berhasil.

Berdasarkan observasi selama pelaksanaan tindakan pada siklus I dan siklus II ditemukan hasil penelitian menunjukkan peningkatan pada beberapa aspek yang ditetapkan dalam penelitian ini. Analisis peningkatan pada kedua aspek tersebut digambarkan dalam grafik batang berikut ini 


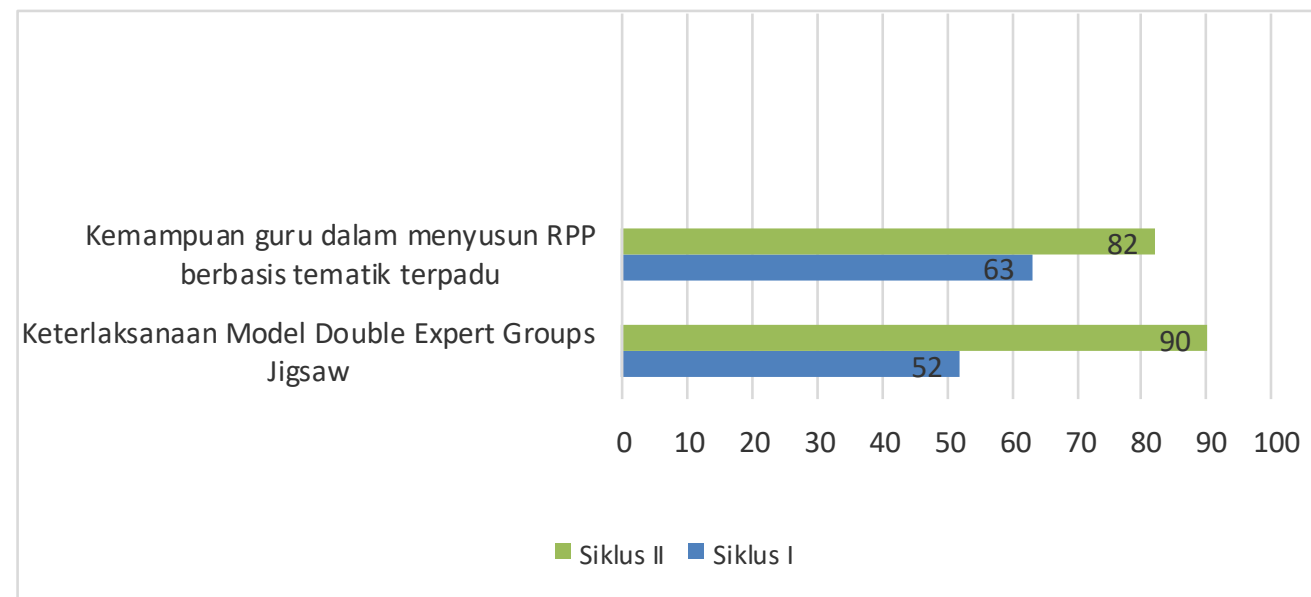

Gambar 2. Grafik Peningkatan Temuan Hasil Penelitian Tindakan pada Siklus I dan

Siklus II.

Berdasarkan grafik di atas, temuan hasil penelitian tindakan pada siklus I dan siklus II mengalami peningkatan yang siginfikan pada aspek keterlaksanaan model Double Expert Groups Jigsaw semula diperoleh hasil sebesar $52 \%$ menjadi 90\%. Sedangkan aspek kemampuan guru dalam menyusun RPP tematik terpadu mengalami peningkatan yang positif pada siklus I hanya mencapai $63 \%$ meningkat menjadi $82 \%$ pada siklus II. Dapat disimpulkan bahwa pembelajaran dengan model Double Expert Groups Jigsaw dapat kemampuan guru dalam menyusun RPP tematik terpadu, sehingga penelitian tidak perlu dilanjutnya ke siklus yang berikutnya.

Masing-masing guru memiliki keberagaman yang dilatarbelakangi oleh pengetahuan. Pengetahuan ini tidak hanya mempengaruhi tingkat pemahaman selama proses penerimaan informasi, tetapi juga mempengaruhi seberapa baik guru tersebut menyimpan informasi dan mentranfernya ke dalam pengetahuan yang baru (Mayer, 2008). Oleh karena itu, melalui kegiatan diskusi diharapkan guru memperoleh kesamaan sudut pandang, mengembangkan keterampilan, meningkatkan kualitas komunikasi sehingga tujuan kelompok dapat tercapai. Manfaat diskusi dalam peningkatan kompetensi diri juga dinyatakan oleh Li et al., (2007) bahwa kelompok menyokong pengembangan skill berkomunikasi, toleransi terhadap perbedaan pendapat, bekerjasama dalam kelompok dan mampu mengkritisi pandangannya dan pandangan orang lain.

Timbulnya kepedulian guru akan kesulitan yang dialami kelompok dan meningkatnya empati guru terhadap sasaran pencapaian kelompok menandakan bahwa guru memiliki kotribusi yang besar dalam kelompok melalui gagasan, ide, saran, dan alternatif jalan keluar kendala. Munculnya sikap-sikap guru membuktikan bahwa model kooperatif ini telah berjalan dengan baik sesuai dengan prinsip model 
$\begin{array}{lcr}\begin{array}{l}\text { kooperatif } \\ \text { Interdependence }\end{array} & \begin{array}{r}\text { Posituive } \\ \text { (kesaling }\end{array} \\ \text { tergantungan } & \text { positif), Individual } \\ \text { Accountability } & \text { (tanggung jawab } \\ \text { individu), } & \text { Equal } & \text { Participation } \\ \text { (partisipasi } & \text { yang } & \text { sama), }\end{array}$ Simultaneous Interaction (interaksi bersama) (Kagan \& Kagan, 2009), sehingga pada akhirnya guru tidak hanya mendapatkan prestasi dan penghargaan, tapi juga memiliki sikap kepedulian, persahabatan, dan hubungan yang sehat dengan teman (Johnson \& Johnson, 2006). Pada prinsipnya kompetensi yang diharapkan dikuasai oleh guru adalah kompetensi dalam merencanakan pembelajaran yang aktif, produktif, efektif, dan bermakna bagi peserta didik. strategi pembelajaran yang dipilih harus diarahkan untuk memfasilitasi pencapaian kompetensi yang telah disusun dalam dokumen kurikulum yang mencakup aspek (1) student centre, (2) mengembangkan kreativitas peserta didik, (3) menciptakan kondisi yang menyenangkan dan menantang, (4) memuat nilai etika, estetika, logika, dan kinestetika, (5) menyediakan pengalaman belajar yang beragam melalui penerapan berbagai strategi dan metode pembelajaran yang menyenangkan, kontekstual, efektif, efisien, dan bermakna (Widyastono, 2014).

Pencapaian wujud pembelajaran student centre oleh guru melalui penerapan dan penelaah-an lima kegiatan belajara siswa (mengamati, menanya, pengumpulan data, mengasosiasi, dan mengomunikasikan). Secara tepat, guru dapat menentukan sasaran aktivitas siswa sesuai tahapan-tahapan kegiatan tersebut.
Selanjutnya, guru mengkolaborasikan lima kegiatan belajar siswa dengan model pembelajaran kooperatif. Sebagaimana yang dikemukakan Slavin (2005) bahwa pembelajaran kooperatif adalah pembelajaran yang melibatkan seluruh siswa belajar bersama-sama, saling menyumbangkan pikiran dan bertanggung jawab terhadap pencapaian hasil belajar, baik secara individu maupun kelompok. Guru secara klasikal mampu mengorganisir siswa dalam kelompok-kelompok tujuan dengan penyebaran berdasarkan akademis siswa, membimbing kelompok untuk belajar, dan menyusun skenario yang memusatkan pada keterlibatan siswa melalui permainan, quiz, dan reward. Kemampuan guru mengaplikasikan model kooperatif pada RPP yang disusun mengindikasikan kesadaran guru terhadap pentingnya pembelajaran yang menyenangkan, tidak hanya berfokus pada hasil namun juga proses (Kagan \& Kagan, 2009).

Moreno (2010) menyatakan banyak penelitian menunjukkan bahwa kualitas metodet ertanam dalam sebuah teknologi yang mempengaruhi belajar siswa dimana penyampaiannya melalui media. Kemampuan guru dalam memanfaatkan media berbasis teknologi dilatarbelakangi oleh usaha dan kemauan untuk belajar serta timbulnya sikap peduli, simpati dan empati oleh guru yang ahli dalam mengopersikan media untuk memberikan bantuan secara mandiri dan spontan. Pemberian bantuan secara spontan ini sangat dibutuhkan kepada guru yang memiliki kemampuan minoritas 
dalam teknologi sehingga menimbulkan motivasi serta kepercayaan diri kepada yang diberi bantuan (Ding et al., 2007). Teknologi tidak hanya merevolusi kegiatan pembelajaran dalam kelas, namun juga mampu mencapai sasaran pembelajaran yang dirancang oleh guru. Pencapaian tujuan pembelajaran melalui media, membantu siswa dalam memahami struktur,meingtegrasikan

pembelajaran yang aktif, dan memfasilitasi penyimpanan pengetahuan (Holden \& Westfall, 2010)

\section{SIMPULAN}

Berdasarkan hasil penelitian dan pembahasan tindakan kelas yang dilakukan peneliti di SDN Tunjungsekar 5 Malang dapat disimpulkan bahwa penerapan model Double Expert Groups Jigsaw dapat meningkatkan kompetensi guru dalam menyusun RPP berbasis tematik terpadu.

Tercapainya kemampuan guru dijembatani oleh kegiatan diskusi kelompok dan tim ahli. Diskusi kelompok yang efektif memberikan peluang kepada guru untuk dapat bertukar pengetahuan, berkomunikasi, serta menimbulkan kepedulian pemberian solusi atau bantuan terhadap kesulitan yang dihadapi kelompok. Tim ahli yang bekerja secara maksimal menyokong motivasi, semangat, dan kualitas kelompok terhadap sasaran yang ditentukan. Sehingga pada akhirnya, guru memiliki kemampuan untuk merancang kegiatan pembelajaran yang bermakna, berpusat pada peserta didik, dan menyenangkan

\section{DAFTAR PUSTAKA}

Anderson, O., \& Krathwohl, D. 2001. A Taxonomy for Learning, Teaching, and Assesing ( $A$ Revision of Bloom's taxonomy of Educational Objectives). New York : Addison Wesley Longman, Inc

Ding, M., Li, X., Piccolo, D., \& Kulm, G. 2007. Teacher Interventions in CooporativeLearning. Journal of Educational Research, 100 (3), 162-176.

Holden, J., \& Westfall, P. 2010. An Instructional Media Selection Guide for Distance Learning.
United States Distance Learning Assiciation.

Johnson, D., \& Johnson, R. 2006. Learning Together and Alone: Cooperation, Competition, and Individualization (8th ed.). Needham Heights, MA: Allyn \& Bacon.

Kagan, S., \& Kagan, M. 2009. Kagan Cooperative Learning. San Clemente: Kagan Publishing.

Kementerian Pendidikan dan Kebudayaan. 2014. Peraturan Menteri Pendidikan dan Kebudayaan Nomor 103 
tentang Pembelajaran pada

Pendidikan Dasar dan

Pendidikan Menengah.

Jakarta: Sekretariat Jenderal.

Kemmis, S., McTaggart, R., Nixon,

R. 2014. The Action

Research Planner. New York:

Springer.

Li, Y., Anderson, R., Nguyien-Jahiel, K., Dong, T., Archodidou, A., Kim, L., Clark, A., Wu, X., Jadallah, M., \& Miller, B. 2007. Emergent Leadership in Children's Discussion Groups. Cognition and Instruction, 25(1), 75-111.

Mayer, R. 2008. Learning and Instruction. Upper Saddle River, NJ: Pearson Education.
Moreno, R. 2010. Educational Psychology. The University of Mexyco: John Wiley \& Sons, Inc.

Slavin, R. 2005. Cooperative Learning: Teori, Riset, dan Praktik. Terjemahan oleh Narulita Yusron. Bandung: Nusa Media.

Widyastono, H. 2014.

Pengembangan Kurikulum Di Era Otonomi Daerah (Dari Kurikulum 2004, 2006 ke Kurikulum 2013). Jakarta: Bumi Aksara.

Wiggins, G., \& McTighe, J. 2005. Understanding By Design (2nd ed.). Upper Saddle River, NJ: Pearson Education. 